\title{
POSSIBILITIES FOR THE EFFECTIVE PURSUANCE OF THE COSTS IN THE PORCELAIN INDUSTRY
}

\author{
PhD Student Sas Florentina, „Valahia”University, Targoviste; sas_florentina2003@yahoo.com
}

\begin{abstract}
The standard cost method promotes the anticipated calculation of the costs of production and the determination, pursuance and the control of the digressions from the costs of production. The standard costs represent preestablished costs of production on strict scientific basis in the conditions imposed by the technological proceedings used for obtaining the products as well as by the organizational and functional structures of the enterprise, valid in the period taken into account The typical structure of a total cost of production calculated by the standard cost method is made of three main articles of the costs' calculation, namely: materials, manpower, indirect costs. By applying the standard cost method in the variant unique standard cost in the enterprises from the porcelain industry, the current effective control and the post-effective control offer bigger advantages than in the case of applying the classical methods of costs' calculation.
\end{abstract}

The costs' calculation in the enterprises from the porcelain industry, made on the basis of the classical methods of management accounting, doesn't allow an effective informing of the management regarding the costs of the production obtained. Taking this into account, a solution would be the application of the standard cost method, the variant unique standard cost in these enterprises.

The standard cost method appeared in the year 1901, in the United States of America, under the name of the Estimated cost system.

The standard cost method promotes the anticipated calculation of the costs of production and the determination, pursuance and the control of the digressions from the costs of production.

The standard costs represent preestablished costs of production on strict scientific basis in the conditions imposed by the technological proceedings used for obtaining the products as well as by the organizational and functional structures of the enterprise, valid in the period taken into account ${ }^{1}$.

We can define the standards as being physical or value measures with character of unit, established in scientific way on the basis of modern methods of recording, pursuance and analysis of the phenomenon that are unfolding in the enterprise.

A standard is a reference or a norm in measuring the performance ${ }^{2}$.

The physical standards, being established on the basis of technical documentations adapted to the specific conditions of the production process, have the advantage of a bigger validity, their change being conditioned by the changes in the technology of production. The physical standards are based on the product that will be made and which requires some materials of standard qualities, standard conditions for unfolding the processes of supply, production, standard manpower, standard stocks of materials, of work in progress.

The value standards have the same stability as the physical standards because of the frequent change of the prices of acquisition, of the raw materials and materials or of the wage tariffs.

Standard costs are established by a process of scientific fact finding which utilizes both past experience and controlled experiment. The process of setting standard costs includes a careful

\footnotetext{
${ }^{1}$ Oprea Calin, Gheorghe Cârstea, The management accounting and the costs' calculation, Genicod Printing House, Bucharest, 2002, p. 198;

${ }^{2}$ R.H. Garrison, Management Accounting. Concepts for Planning, Control, Decision making, Fifth Edition, BPI/IRWIN, 1988, p. 383;
} 
selection of materials, time and motion studies of operations and an engineering study of equipment and other manufacturing facilities ${ }^{3}$.

From the methodological point of view, this method is based on the classification of the expenditures in direct and indirect expenditures on one way, and in variable, semivariable and fixed expenditures, on the other way.

The typical structure of a total cost of production calculated by the standard cost method is made of three main articles of the costs' calculation, namely: materials, manpower, indirect costs.

This method is characterized by the fact that the standards that are preestablished costs, are considered real costs or normal costs of production. Thus, the costs' calculation is reduced to a single calculation, namely the standard costs' calculation that represents the basis of fixing the selling prices, not being necessary the calculation of the effective cost of the products. The differences in plus or in minus between the effective expenditures and the standard expenditures are considered digressions from the normal conditions of production and affects directly the final results of the enterprise in the respective period.

The digressions have a central place in the general conception of the management accounting and of the costs' calculation based on the utilization of the standard costs. This fact reflects the degree of organization of the activity, the observance of the technological discipline, the placing or not placing the programmed level in the process of production, supply and sell.

The synthetic and analytic accounting should solve the following ${ }^{4}$ :

- the collecting and the delimitation on articles of calculation of the level of the standard expenditures of the finished products made;

- the discrete recording of the digressions from the standard expenditures, considered from the phase of technicaleconomic design of the level of the cost of production, as normal expenditures of production;

- on each product it must be assured the recording of the production made, evaluated in standard costs.

The pursuance of the costs of production through the management accounting in the case of the standard cost method can be organized in one of the following variants: partial standard cost, unique standard cost and double standard cost.

In the case of the variant standard cost unique, the account 921 "The expenditures of the basic activity" displayed in analytic on sectors or workshops and on articles of calculation, is debited with the materials consumed, the manpower and the overhead expressed in standard costs of the production obtained and is credited with the standard costs of the finished products obtained. The balance represents the standard costs of the work in progress. For determining this there is no necessary to make an inventory. Regarding the digressions, these are calculated by the proceedings known on causes on each article of calculation. For direct raw materials and materials, the digressions from the price difference can be established in the moment of their supply and deposit or in the moment of their consuming. The other digressions will be determined when the process of production takes place. The digressions determined are recorded in the account 903 "Internal discounts regarding the price differences" unfolded in analytic on sectors of expenditures and on articles of calculation. This account is debited with the exceeding from the standard costs and is credited with the economies from these costs. Its balance is then taken over in the account of results. The establish of the digressions regarding the raw materials and the direct manpower on the basis of the documents and not on the accounting way, creates the premises for the effective informing of the factors of decisions about the disorders in the process of production. The sums reported effectively must be periodically confronted with those recorded into accounting. The supplementary

\footnotetext{
${ }^{3}$ Walter B. McFarland, The Basic Theory of Standard Costs, The Accounting Review, Vol. 14, No. 2, Jun., 1939, p. 151-158;

${ }^{4}$ Sorin Briciu, The management accounting. Theoretical and practical aspects, Economic Printing House, Bucharest, 2006, p. 187;
} 
effort imposed by the determination and effective reporting is compensated by the fact that in the standard cost unique method it is not obligatory the inventory of the work in progress.

\section{Example:}

The standard for the direct raw materials and materials for the dinner plate 520 grams is:

Table no. 1.

\begin{tabular}{|l|l|r|r|r|}
\hline $\begin{array}{c}\text { Direct raw materials and } \\
\text { materials }\end{array}$ & M.U. & $\begin{array}{c}\text { Quantitative } \\
\text { standard }\end{array}$ & $\begin{array}{c}\text { Cost of acquisition } \\
\text { RON/M.U. }\end{array}$ & $\begin{array}{c}\text { Value standard } \\
\text { RON }\end{array}$ \\
\hline Kaolin & $\mathrm{Kg}$ & 0,200 & 1,5 & 0,30 \\
\hline Feldspar & $\mathrm{Kg}$ & 0,250 & 1,0 & 0,25 \\
\hline Sand & $\mathrm{Kg}$ & 0,200 & 1,0 & 0,20 \\
\hline Gold & $\mathrm{L}$ & 0,100 & 4,0 & 0,40 \\
\hline Decor & Pieces & 4,000 & 0,2 & 0,80 \\
\hline Package & Pieces & 0,010 & 5,0 & 0,05 \\
\hline Total & & & & $\mathbf{2 , 0 0}$ \\
\hline
\end{tabular}

For the production of 2.000 dinner plates of 520 grams, the standard cost of the direct raw materials and materials is: $2.000 \times 2=4.000 \mathrm{RON}$.

The standard for the direct manpower for the dinner plate 520 grams is:

Table no. 2.

\begin{tabular}{|l|l|l|r|r|r|r|r|}
\hline No. & \multicolumn{1}{|c|}{ Phase } & M.U. & \multicolumn{1}{|c|}{$\begin{array}{c}\text { Standard } \\
\text { time }\end{array}$} & $\begin{array}{c}\text { Standard } \\
\text { wage tariff } \\
\text { RON/hour }\end{array}$ & $\begin{array}{c}\text { Value } \\
\text { standard } \\
\text { RON }\end{array}$ & $\begin{array}{c}\text { Contributions } \\
\text { for the } \\
\text { salaries RON }\end{array}$ & $\begin{array}{c}\text { Total value } \\
\text { standard RON }\end{array}$ \\
\hline 1. & Preparation & Min. & $30 \mathrm{~min}$ & 0,020 & 0,010 & 0,004 & 0,014 \\
\hline 2. & Shaping & Min. & $1 \mathrm{~h}$ & 0,015 & 0,015 & 0,006 & 0,021 \\
\hline 3. & Burning & Min. & $1 \mathrm{~h} 30 \mathrm{~min}$ & 0,033 & 0,050 & 0,020 & 0,070 \\
\hline 4. & Decorating & Min. & $10 \mathrm{~min}$ & 0,060 & 0,010 & 0,004 & 0,014 \\
\hline 5. & Sorting & Min. & $5 \mathrm{~min}$ & 0,060 & 0,005 & 0,002 & 0,007 \\
\hline 6. & Packing & Min. & $5 \mathrm{~min}$ & 0,060 & 0,005 & 0,002 & 0,007 \\
\hline $\mathbf{7 .}$ & Total & & & & $\mathbf{0 , 0 9 5}$ & $\mathbf{0 , 0 3 8}$ & $\mathbf{0 , 1 3 3}$ \\
\hline
\end{tabular}

For he production of 2.000 dinner plates, of 520 grams, the standard cost of the direct manpower is: $2.000 \times 0,133=266 \mathrm{RON}$.

The standard overhead is $1.000 \mathrm{RON}$, out of which $600 \mathrm{RON}$ are the variable expenditures, $150 \mathrm{RON}$ are the semivariable expenditures and $250 \mathrm{RON}$ are the fixed expenditures. The standard hours for the overhead are 400 and the standard tariff is 2 RON/hour.

The effective production obtained is 1.800 plates.

The effective cost of the direct raw materials and materials for the dinner plate 520 grams is:

Table no. 3 .

\begin{tabular}{|l|l|c|r|r|}
\hline $\begin{array}{c}\text { Direct raw materials } \\
\text { and materials }\end{array}$ & M.U. & $\begin{array}{c}\text { Effective } \\
\text { consume }\end{array}$ & $\begin{array}{c}\text { Effective cost of } \\
\text { acquisition RON/M.U. }\end{array}$ & $\begin{array}{c}\text { Effective values } \\
\text { RON }\end{array}$ \\
\hline Kaolin & $\mathrm{Kg}$ & 0,180 & 1,6 & 0,29 \\
\hline Feldspar & $\mathrm{Kg}$ & 0,230 & 1,1 & 0,25 \\
\hline Sand & $\mathrm{Kg}$ & 0,220 & 1,1 & 0,24 \\
\hline Gold & $\mathrm{L}$ & 0,080 & 4,2 & 0,34 \\
\hline Decor & Pieces & 4,000 & 0,2 & 0,8 \\
\hline Package & Pieces & 0,010 & 6,0 & 0,06 \\
\hline Total & & & & $\mathbf{1 , 9 8}$ \\
\hline
\end{tabular}


For the production of 1.800 dinner plates of 520 grams, the effective cots of the direct raw materials and materials is: $1.800 \times 1,98=3.564 \mathrm{RON}$.

The effective cost of the direct manpower for the dinner plate of 520 grams is:

Table no. 4.

\begin{tabular}{|c|l|r|r|r|r|r|r|}
\hline No. & \multicolumn{1}{|c|}{ Phase } & M.U. & \multicolumn{1}{c|}{$\begin{array}{c}\text { Effective } \\
\text { time }\end{array}$} & $\begin{array}{c}\text { Effective wage } \\
\text { tariff } \\
\text { RON/hour }\end{array}$ & $\begin{array}{c}\text { Effective } \\
\text { values } \\
\text { RON }\end{array}$ & $\begin{array}{c}\text { Contributions } \\
\text { for the salaries } \\
\text { RON }\end{array}$ & $\begin{array}{c}\text { Total direct } \\
\text { manpower } \\
\text { RON }\end{array}$ \\
\hline 1. & Preparation & Min. & $20 \mathrm{~min}$ & 0,03 & 0,010 & 0,004 & 0,014 \\
\hline 2. & Shaping & Min. & $45 \mathrm{~min}$ & 0,02 & 0,015 & 0,006 & 0,021 \\
\hline 3. & Burning & Min. & $1 \mathrm{~h} 30 \mathrm{~min}$ & 0,04 & 0,060 & 0,024 & 0,084 \\
\hline 4. & Decorating & Min. & $8 \mathrm{~min}$ & 0,07 & 0,009 & 0,004 & 0,013 \\
\hline 5. & Sorting & Min. & $4 \mathrm{~min}$ & 0,07 & 0,005 & 0,002 & 0,007 \\
\hline 6. & Packing & Min. & $4 \mathrm{~min}$ & 0,07 & 0,005 & 0,002 & 0,007 \\
\hline 7. & Total & & & & $\mathbf{0 , 1 0 4}$ & $\mathbf{0 , 0 4 2}$ & $\mathbf{0 , 1 4 6}$ \\
\hline
\end{tabular}

For the production of 1.800 dinner plates, the effective cost of the manpower is: $1.800 \times 0,146$ $=262,80 \mathrm{RON}$.

The effective overhead is $1.150 \mathrm{RON}$, out of which $650 \mathrm{RON}$ are the variable expenditures, $200 \mathrm{RON}$ are the semivariable expenditures and $300 \mathrm{RON}$ are the fixed expenditures. The effective hours for overhead are 380 and the effective tariff is 2,5 RON/hour.

A) The digressions from the consumption of direct raw materials and materials are:

a) The digressions of quantity:

$$
\mathrm{D}_{\mathrm{CM}}=\sum_{i=1}^{n}[(\mathrm{Ce}-\mathrm{Cs}) \times \mathrm{Ps}]_{\mathrm{n}} \mathrm{x} \text { qe }
$$

where: $\mathrm{Ce}-$ the effective consumption;

$\mathrm{Cs}$ - the standard consumption;

Ps - the standard price of supply;

qe - the effective quantity;

$\mathrm{n}$ - type of raw materials.

The calculation of the digressions for the quantity is:

- Kaolin: $\quad(0,180-0,200) \times 1,5 \times 1.800=-54$

- Feldspar: $\quad(0,230-0,250) \times 1,0 \times 1.800=-36$

- Sand: $\quad(0,220-0,200) \times 1,0 \times 1.800=36$

- Gold: $\quad(0,080-0,100) \times 4,0 \times 1.800=-144$

- Decor: $\quad(4-4) \times 0,2 \times 1.800 \quad=0$

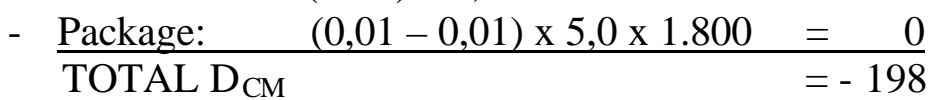

b) The digressions from differences of price: $\quad \mathrm{D}_{\mathrm{PM}}=\sum_{i=1}^{n}[(\mathrm{Pe}-\mathrm{Ps}) \times \mathrm{Ce}]_{\mathrm{n}} \times \mathrm{qe}$

The calculation of the digressions from the differences of price is:

- Kaolin: $\quad(1,6-1,5) \times 0,180 \times 1.800=32,4$

- Feldspar: $\quad(1,1-1,0) \times 0,230 \times 1.800=41,4$

- Sand: $\quad(1,1-1,0) \times 0,220 \times 1.800=39,6$

- Gold: $\quad(4,2-4,0) \times 0,08 \times 1.800=28,8$

- Decor: $\quad(0,2-0,2) \times 4,0 \times 1.800=0$

- Package: $\quad(6,0-5,0) \times 0,01 \times 1.800=18$

TOTAL DPM $=160,2$


The digressions from the standard costs for raw materials: $D_{\mathrm{VM}}=\mathrm{D}_{\mathrm{CM}}+\mathrm{D}_{\mathrm{PM}}=-198+160,2$ $=-37,8 \mathrm{RON}$

B) The total digression for the manpower $\left(D_{W}\right)$ can be calculated by the formula:

$$
\mathrm{D}_{\mathrm{W}}=\mathrm{D}_{\mathrm{H}}+\mathrm{D}_{\mathrm{T}}
$$

a) the digressions from the efficiency of work $\left(\mathrm{D}_{\mathrm{H}}\right)$ are calculated by the relation:

$$
\mathrm{D}_{\mathrm{H}}=\sum_{i=1}^{n}\left[(\mathrm{He}-\mathrm{Hs}) \times \mathrm{T}_{\mathrm{S}}\right]_{\mathrm{n}} \times \mathrm{qe}
$$

where: $\mathrm{He}$ - the hours effectively worked;

Hs - the standard hours;

Ts - the standard wage tariff;

qe - the effective quantity;

$\mathrm{n}$ - type of the phases of production.

- Preparation: $(0,33-0,50) \times 0,02 \times 1.800=-6,12$

- Shaping: $\quad(0,75-1) \times 0,015 \times 1.800=-6,75$

- Burning: $\quad(1,5-1,5) \times 0,033 \times 1.800=0$

- Decorating: $(0,13-0,17) \times 0,06 \times 1.800=-4,32$

- Sorting: $\quad(0,07-0,08) \times 0,06 \times 1.800=-1,08$

- Packing: $\quad(0,07-0,08) \times 0,06 \times 1.800=-1,08$

TOTAL $\mathrm{D}_{\mathrm{H}}=-19,35$

b) the digressions from the wage tariff $\left(\mathrm{D}_{\mathrm{T}}\right): \mathrm{D}_{\mathrm{T}}=\sum_{i=1}^{n}[(\mathrm{Te}-\mathrm{Ts}) \times \mathrm{He}]_{\mathrm{n}} \times \mathrm{qe}$

- Preparation: $(0,03-0,02) \times 0,33 \times 1.800=5,94$

- Shaping: $\quad(0,02-0,015) \times 0,75 \times 1.800=6,75$

- Burning: $\quad(0,04-0,033) \times 1,5 \times 1.800=18,9$

- Decorating: $(0,07-0,06) \times 0,13 \times 1.800=2,34$

- Sorting: $\quad(0,07-0,06) \times 0,07 \times 1.800=1,26$

$\begin{array}{ll}\text { - Packing: } \quad(0,07-0,06) \times 0,07 \times 1.800 & =1,26 \\ \text { TOTAL } \mathrm{D}_{\mathrm{T}} & =36,45\end{array}$

The digressions from the standard costs for the manpower are:

$$
\mathrm{D}_{\mathrm{W}}=\mathrm{D}_{\mathrm{H}}+\mathrm{D}_{\mathrm{T}}=-19,35+36,45=17,10 \mathrm{RON} \text {. }
$$

c) The digressions from the standard overhead:

The total digression from the budget is calculated as a difference between the effective expenditures (Ee) and the budgeted expenditures (Es):

$\Delta \mathrm{Eb}=\mathrm{Ee}-\mathrm{Es}=1.150-1.000=150 \mathrm{RON}$

The digression from the recalculated budget is determined because of the necessity to correlate the overhead with the volume of the activity unfolded which digresses from the standard volume. The recalculation is made only for the variable and semivariable expenditures because the fixed expenditures don't change according to the changes in the volume of the production.

The recalculation of the variable expenditures is based on one of the following relations:

$$
\begin{aligned}
& \text { Evr }=\frac{\text { Evs }}{\text { Vhs }} \times \text { Vhe } \\
& \text { Evr }=\frac{\text { Vhe }}{\text { Vhs }} \times \text { Evs }
\end{aligned}
$$


where: Evs - the standard variable expenditure;

Vhs - the volume of the standard activity in hours;

Vhe - the volume of the effective activity in hours.

$$
\text { Evr }=\frac{380}{400} \times 600=570 \mathrm{RON}
$$

The recalculation of the semivariable expenditures is based on the relation:

where:

$$
\text { Esvr }=\text { Esvs }+[\text { esv } \times(\text { Vhe }- \text { Vhs })]
$$

Esvr - the semivariable expenditure recalculated;

Esvs - the standard semivariable expenditure;

esv - the standard variable hour quota regarding the variable part of the expenditure.

Esvr $=150+[2 \times(380-400)]=110 \mathrm{RON}$

The admissible budget $=\mathrm{Evr}+\mathrm{Esvr}+\mathrm{Ef}=570+110+250=930 \mathrm{RON}$

Effective overhead $=1.150 \mathrm{RON}$

$\Delta \mathrm{Ebr}=1.150-930 \mathrm{RON}=220 \mathrm{RON}$

The digression from the unused capacity or unused standard time is determined by taking as a basis the standard overhead related to the effective volume of the production. It can be calculated in two ways:

- by comparing the standard overhead related to the effective hours of productive activity with the standard overhead:

$$
\Delta \text { Eqs }=\text { Es } \times \frac{\text { Vhe }}{\text { Vhs }}-\text { Es }=1.000 \times \frac{380}{400}-1.000=-50
$$

- by comparing the standard overhead related to the effective hours of productive activity with the standard overhead recalculated:

$$
\Delta \text { Eqs }=\text { Es } \times \frac{\text { Vhe }}{\text { Vhs }}-\mathrm{Er}=1.000 \times \frac{380}{400}-930=20
$$

In the first variant the digression of capacity represents an economy because the production made being bigger than the standard production, the capacity of the enterprise is better used, the quota of the fixed expenditures on the unit of product is reduced and is lower than the standard one. In the second variant, the digression of capacity represents an exceeding of the recalculated expenditures because the standard expenditures of the effective production are bigger than those related to the standard production, so the degree of use of the capacity of production requires a bigger volume of overhead than the real one.

The digressions of efficiency represent the difference between the standard costs related to the effective hours of activity and standard costs for the production made:

where: Qe - the effective volume of production;

$$
\Delta \text { Ers }=\text { Es } x \frac{\text { Vhe }}{\text { Vhs }}-\text { Es } \times \frac{\text { Qe }}{\text { Qs }}
$$

Qs - the standard volume of production.

$$
\Delta \text { Ers }=1.000 \times \frac{380}{400}-1.000 \times \frac{1.800}{2.000}=950-900=50 \mathrm{RON}
$$

The total digression:

$$
\Delta \mathrm{ET}=\Delta \mathrm{Eb}+\Delta \mathrm{Eqs}+\Delta \mathrm{Ers}=150-50+50=150 \mathrm{RON}
$$

The accounting records are: 
1. The recording of the standard direct raw materials:

921.1 "The expenditures of the basic activity” = $\quad 901$ „Internal discounts regarding the expenditures” $\underline{4.000}$ Raw materials

2. The recording of the standard direct manpower:

921.2 „The expenditures of the basic activity” $\quad=\quad 901$ „Internal discounts regarding the expenditures” $\underline{266}$ Direct manpower

3. The recording of the standard overhead:

923 „Overhead”

$=901$, ,Internal discounts regarding the expenditures”

4. The allocation of the overhead:

921.3 „The expenditures of the basic activity” Overhead $=923$ „Overhead”

5. The recording of the digressions of quantity and price of the raw materials:

931.1 „The cost of production”- Raw materials

$=$

903.1.1 „Internal discounts regarding the price

differences" Raw materials Quantity

903.1.2 „Internal discounts regarding the price differences" Raw materials Price

6. The recording of the digressions of time and tariff of the manpower:

931.2 „The cost of production”- Direct manpower
$=\frac{\%}{903.2 .1 \text {,Internal discounts regarding the price }}$ differences" Direct manpower Time
903.2.2 „Internal discounts regarding the price differences" Direct manpower Tariff

$\frac{17,10}{(19,35)}$

36,45

$\underline{150}$

150

903.3.1 „Internal discounts regarding the price differences" Overhead Volume

903.3.2 „Internal discounts regarding the price differences" Overhead Capacity

903.3.3 ,Internal discounts regarding the price differences" Overhead Efficiency

8. The recording of the production obtained at standard cost:

931.1 „The cost of production”- Raw materials

$=902$,Internal dis counts regarding the production”

9. The discount of the standard costs related to the finished products obtained:

901 „Internal discounts regarding the expenditures”

$=$
921.1 „The expenditures of the basic activity”
Raw materials
921.2 ,The expenditures of the basic activity”
Direct manpower

921.3 ,The expenditures of the basic activity” Overhead 
10. The closing of the accounts of price differences:

$\%$

$=902$,Internal discounts regarding the production”

$\underline{129,30}$

$(198,00)$ differences" Raw materials Quantity

903.1.2 „Internal discounts regarding the price differences" Raw materials Price

903.2.1 „Internal discounts regarding the price differences" Direct manpower Time

903.2.2 „Internal discounts regarding the price differences" Direct manpower Tariff

903.3.1 „Internal discounts regarding the price differences" Overhead Volume

903.3.2 „Internal discounts regarding the price differences" Overhead Capacity

903.3.3 „Internal discounts regarding the price differences" Overhead Efficiency

11. The closing of the account 931 ,The cost of production”:

902 „Internal discounts regarding the production” =

$\%$

$\underline{5.136,70}$

$4.037,80$

931.1 „The cost of production” - Raw materials

931.2 „The cost of production” - Direct manpower

850,00

12. The recording of the result of the period:

902 „Internal discounts regarding the production” = 932 „The result of the period”

$\underline{259,30}$

By applying the standard cost method in the variant unique standard cost in the enterprises from the porcelain industry, the current effective control and the post-effective control offer bigger advantages than in the case of applying the classical methods of costs' calculation, because there can be analysed rapidly the digressions between the effective and standard expenditures on places of expenditures, on types and on causes in order to take the measures regarding the elimination of the negative effects caused by them and of the causes that generated them.

The need of the enterprises to operate with costs of production determined scientifically and controllable is a reality recognized by the practice and the methods of calculation based on standards established with anticipation for the costs' calculation answer the needs of the technological processes and to the organizational structures of the enterprises.

In terms of the increasing degree of complexity of the activity, the management accounting must face superior requirements. This fact can be made only in the terms of combining the advantages of different methods according to the specific of the activity, in order to allow the management to control the costs in the operative phase of the process of management.

\section{References:}

1. Briciu Sorin, The management accounting. Theoretical and practical aspects, Economic Printing House, Bucharest, 2006;

2. Calin Oprea, Cârstea Gheorghe, The management accounting and the costs' calculation, Genicod Printing House, Bucharest, 2002;

3. Cristea Horia, Accounting and Calculations in Enterprise's Management, Mirton Printing House, Timisoara, 1997.

4. McFarland Walter B., The Basic Theory of Standard Costs, The Accounting Review, Vol. 14, No. 2, Jun., 1939;

5. Garrison R.H., Management Accounting. Concepts for Planning, Control, Decision making, Fifth Edition, BPI/IRWIN, 1988. 